\title{
Assessment of fish assemblages in streams of different orders in the Upper Paraná River basin, Central Brazil
}

\author{
Thiago B. Vieira ${ }^{2} \&$ Francisco L. Tejerina-Garro ${ }^{2}$
}

\footnotetext{
1. Programa de Pós-Graduação em Ecologia e Evolução, Universidade Federal de Goiás, Instituto de Ciências Biológicas, Departamento de Ecologia, Rodovia Goiânia-Nerópolis km 5, Campus II Itatiaia, 74001-970, Goiânia, GO, Brazil. (thiagobernardi007@gmail.com)

2. Centro de Biologia Aquática, Pontifícia Universidade Católica de Goiás - Campus II, Av. Engler s/n, Jardim Mariliza, 74605-010, Goiânia, GO, Brazil. (garro@pucgoias.edu.br)
}

\begin{abstract}
The aim of this study was to test whether the richness observed and the biomass per trophic group of fish assemblages vary depending on the order $\left(1^{\text {st }}\right.$ and $\left.2^{\text {nd }}\right)$ of the streams located in three different basins of the Upper Paraná River Basin, Central Brazil. Samples were collected between April and September, 2009, in 27 streams of the Meia Ponte, Piracanjuba and Santa Maria River basins. A total of 4,879 specimens were collected distributed in 59 species and 19 families. The statistical analyses carried out indicate that the observed richness and biomass of omnivore fish were influenced by the interaction of two factors: stream order and basin. The $2^{\text {nd }}$ order streams located in the Santa Maria basin presented significant differences in the observed richness and omnivore biomass when compared to i) $1^{\text {st }}$ order streams in the same basin (only richness) or in the Piracanjuba and Meia Ponte basin; ii) $2^{\text {nd }}$ order streams in the Piracanjuba (only omnivore biomass) and Meia Ponte Rivers basins. Results are discussed considering the influence of geomorphic processes on fish assemblages and food availability.
\end{abstract}

KEYWORDS. Trophic guilds, omnivores, richness, biomass.

RESUMO. Avaliação das assembleias de peixes de riachos de diferentes ordens na bacia do alto rio Paraná, Brasil Central. O objetivo deste estudo foi testar se a riqueza observada e a biomassa por grupo trófico das assembleias de peixes variam de acordo com a ordem $\left(1^{\mathrm{a}} \mathrm{e} 2^{\mathrm{a}}\right)$ dos riachos localizados em três bacias diferentes do sistema do alto rio Paraná, Brasil Central. As amostras foram coletadas entre abril e setembro de 2009 em 27 riachos das bacias dos rios Meia Ponte, Piracanjuba e Santa Maria. Um total de 4.879 espécimes foi coletado distribuídos em 59 espécies e 19 famílias. As análises estatísticas realizadas indicam que a riqueza observada e a biomassa de peixes onívoros foram influenciadas pela interação de dois fatores: a ordem do riacho e a bacia. Os riachos de $2^{\mathrm{a}}$ ordem localizados na bacia do rio Santa Maria apresentaram diferenças significativas de riqueza observada e biomassa de onívoros, quando comparado: i) aos riachos de $1^{\mathrm{a}}$ ordem da mesma bacia (somente a riqueza), da bacia do rio Piracanjuba ou do Meia Ponte; ii) aos riachos de $2^{\mathrm{a}}$ ordem da bacia do rio Piracanjuba (somente a biomassa de omnívoros) ou do rio Meia Ponte. Os resultados obtidos são discutidos considerando a influência dos processos geomórficos sobre a assembleia de peixes e a disponibilidade de alimento.

PALAVRAS-CHAVE. Guildas tróficas, omnívoros, riqueza, biomassa.

Identifying patterns of distribution of richness and abundance of species and relating these to environmental variations is one of the major goals of studies on the ecology of streams (GILler \& MALMQVIST, 1998). One way to explain these patterns of richness and abundance is by using the physical parameters of the drainage network (JONES III et al., 1999; TAYlor et al., 2006; Fialho et al., 2007; Araujo \& Tejerina-Garro, 2009; Kashiwagi \& Miranda, 2009), such as the drainage basin and stream order.

A drainage basin is a set of small water bodies which come together at a certain point to form a larger body of water. It is considered an isolated unit, as it is bordered by oceans and/or large areas of land, which act as barriers to the dispersal of species, thereby leading to differentiation between aquatic communities located in different drainage basins and, in some cases, to speciation (Hugueny et al., 2010). On the other hand, drainage basins can differ from one to another with respect to climate, vegetation, geology and topography which control the geomorphic process and influences on aquatic ecosystems (MonTGOMERY, 1999), thereby bringing differences between fish assemblages in different drainage basins (MAGALHÃEs et al., 2002).

Stream order (STRAhLER, 1957) is useful for evaluating fish distribution in streams because of its influence on fish assemblage, but by itself, it is not a pervasive organizer of lotic fish assemblages (MATTHEws, 1986). Studies about this influence indicate that increasing stream order results in the increased richness (WHITESIDE \& McNatt, 1972; Platts, 1979; Osborne \& Wiley, 1992; IbaÑEZ et al., 2009), abundance (SMith \& KRAFt, 2005) and diversity (HARREL et al., 1967; GORMAN \& KARR, 1978) of fish assemblage in temperate and tropical streams. This trend is attributed to i) addition and/or replacement of species (BEECHER et al., 1988) brought about by changes in the abiotic characteristics of stream (SMITH \& KRAFT, 2005), which tend to increase the complexity of the aquatic habitat represented, for example, by stream depth and width, bottom type and current (GORMAN \& KARR, 1978; PlatTs, 1979); ii) shorter distance to downstream source population; iii) reduced barriers to migration from downstream locations; iv) more stable habitats downstream (WINEMILLER et al., 2008).

In headwater courses ( $1^{\text {st }}$ to $3^{\text {rd }}$ order) the main source of energy available is allochthonous organic matter (VANNOTE et al., 1980; Uieda \& MotTA, 2007), which is used as a direct (REDFORD \& FonsECA, 1996) or indirect (WALKER et al., 1990) source of food by local fish assemblages. The trophic composition of these assemblages is persistent over time (MEFFE \& BerRA, 1988) and is composed of fish which occupy almost the entire spectrum of trophic 
niches which occur in aquatic communities (WINEMILLER et al., 2008). Insectivores dominate headwater courses (PALLER, 1994), whereas omnivores tend to increase with stream order (SMiley JR et al., 2005; Winemiller et al., 2008; IBAÑEZ et al., 2009).

Against this background, the aim of this study was to test whether (i) the richness observed and (ii) the biomass per trophic group of fish assemblages vary depending on the order ( $1^{\text {st }}$ and $\left.2^{\text {nd }}\right)$ of the streams located in three different basins of the Upper Paraná River Basin, Central Brazil.

\section{MATERIALS AND METHODS}

Samples were collected between April and September, 2009, in 27 streams located in the basins of the Meia Ponte (7 streams), Piracanjuba (14) and the Santa Maria Rivers (6), in southeastern of State of Goiás, in the Upper Paraná River basin, Central Brazil (Fig. 1). The Santa Maria River basin presents streams with substrates composed predominantly of sand and gravel and with higher channel width (mean $=5.8 \mathrm{~m}$, standard error $=$ $\pm 0.5)$, depth $(0.4 \mathrm{~m}, \pm 0.04)$ and water velocity $(279.9$ $\mathrm{cm} / \mathrm{s}, \pm 34.7 \mathrm{~cm} / \mathrm{s})$, than streams in the Piracanjuba (2.4 $\mathrm{m}, \pm 0.3 \mathrm{~m} ; 0.2 \mathrm{~m}, \pm 0.04 \mathrm{~m} ; 243.1 \mathrm{~cm} / \mathrm{s}, \pm 51.4 \mathrm{~cm} / \mathrm{s}$, respectively) or Meia Ponte River basins $(2.5 \mathrm{~m}, \pm 0.8 \mathrm{~m}$; $0.3 \mathrm{~m}, \pm 0.06 \mathrm{~m} ; 185.9 \mathrm{~cm} / \mathrm{s}, \pm 68.5 \mathrm{~cm} / \mathrm{s}$, respectively), where the predominant substrate is sand.

The climate of the region in which the sampled basins are situated ranges from humid to sub-humid, according to the Köppen classification, with two distinct seasons, the rainy season from October to March and the dry season from April to September (BRASIL, 1977). Fishes were sampled during the dry season when flows are low thus making for a more efficient capture (PEASE et al., 2012).

The sections sampled in each stream were selected according to their accessibility. Two 100-meter stretches were demarcated and geo-referenced in each stream, one downstream and the other upstream from the access point, $15 \mathrm{~m}$ distant from each other. For all analyses, data from the two stretches were grouped. All streams sampled were located away from urban areas and surrounded by grasslands, except for the P17 stretch, which was encircled by a sugarcane plantation. All stretches presented riparian forest which, in some cases, had been replaced by grass for feeding cattle (P5) or swamps (P9).

Stream order (Tab. I) was determined using Strahler's modification of Horton's scale (PetTs, 1994) and checked by means of a geographical information system map $(1: 250,000)$ (Sistema Estadual de Estatística e de InFormaÇão GEOGRÁFICA DE GoIÁs, 2013).

Fish sampling was conducted in the morning (7:0012:00) using electrofishing and following the modified protocol of MAzzoni et al. (2000). Each $100 \mathrm{~m}$ stretch was covered just once instead of three times in a downstreamupstream direction. The sampling effort was $1 \mathrm{~h} / 100 \mathrm{~m}$ which was repeated in each stream sampled.

Afterwards, the fish were packed in plastic bags, containing an identification tag, fixed in $10 \%$ formalin and subsequently preserved in $70 \%$ alcohol. In the laboratory, the fish were weighed $(\mathrm{g})$, measured (standard length $\mathrm{mm}$ ) and identified to the lowest taxonomic level possible.

Classification of the species by trophic guild was based on the literature available, with preference given wherever possible to studies undertaken in lotic environments of the Upper Paraná River basin (Tab. II). In the case of species identified at genus level, trophic guild of species of the same genus was used. Thus, the following guilds were considered: (i) Carnivores - species which feed on fish and/or molluscs, decapods, microcrustaceans and other invertebrates but not insects; (ii) Detritivores - fish which feed on detritus (sediments and periphyton); (iii) Insectivores, which consume aquatic or terrestrial insects (adult or larvae) and arachnids; (iv) Omnivores - species which feed indiscriminately on vegetal and animal.

The difference between the fish assemblages was evaluated by using two generalized linear mixed models (GLMM) with nested design separately. This was chosen since the sampled streams are $1^{\text {st }}$ and $2^{\text {nd }}$ order and are grouped (nested) within each of the three basins considered (Tab. I). The first analysis was performed considering observed richness as a dependent variable, stream order as a fixed effect and basin and abundance as a random effect; the second analysis used data per trophic guild (biomass) as a dependent variable, stream order as a fixed effect and basin as a random effect. The use of biomass is appropriate when dealing with trophic guilds because it represents all

Tab. I. Streams sampled between April and September, 2009, in the Upper Paraná River basin, Central Brazil, by basin and order.

\begin{tabular}{|c|c|c|}
\hline Basin & Stream & Order \\
\hline \multirow[t]{7}{*}{ Meia Ponte } & P7 & $1^{\text {st }}$ \\
\hline & P11 & $2^{\text {nd }}$ \\
\hline & P12 & $1^{\mathrm{st}}$ \\
\hline & P19 & $2^{\text {nd }}$ \\
\hline & P20 & $1^{\mathrm{st}}$ \\
\hline & P23 & $2^{\text {nd }}$ \\
\hline & P27 & $2^{\text {nd }}$ \\
\hline \multirow[t]{14}{*}{ Piracanjuba } & $\mathrm{P} 1$ & $2^{\text {nd }}$ \\
\hline & P2 & $1^{\mathrm{st}}$ \\
\hline & P3 & $1^{\text {st }}$ \\
\hline & P4 & $1^{\text {st }}$ \\
\hline & P5 & $2^{\text {nd }}$ \\
\hline & P6 & $1^{\mathrm{st}}$ \\
\hline & P8 & $1^{\mathrm{st}}$ \\
\hline & P9 & $2^{\text {nd }}$ \\
\hline & $\mathrm{P} 10$ & $1^{\mathrm{st}}$ \\
\hline & P21 & $1^{\text {st }}$ \\
\hline & P22 & $2^{\text {nd }}$ \\
\hline & P24 & $1^{\mathrm{st}}$ \\
\hline & P25 & $1^{\text {st }}$ \\
\hline & P26 & $1^{\mathrm{st}}$ \\
\hline \multirow[t]{6}{*}{ Santa Maria } & P13 & $2^{\text {nd }}$ \\
\hline & P14 & $2^{\text {nd }}$ \\
\hline & P15 & $1^{\mathrm{st}}$ \\
\hline & P16 & $2^{\text {nd }}$ \\
\hline & P17 & $1^{\mathrm{st}}$ \\
\hline & $\mathrm{P} 18$ & $2^{\text {nd }}$ \\
\hline
\end{tabular}




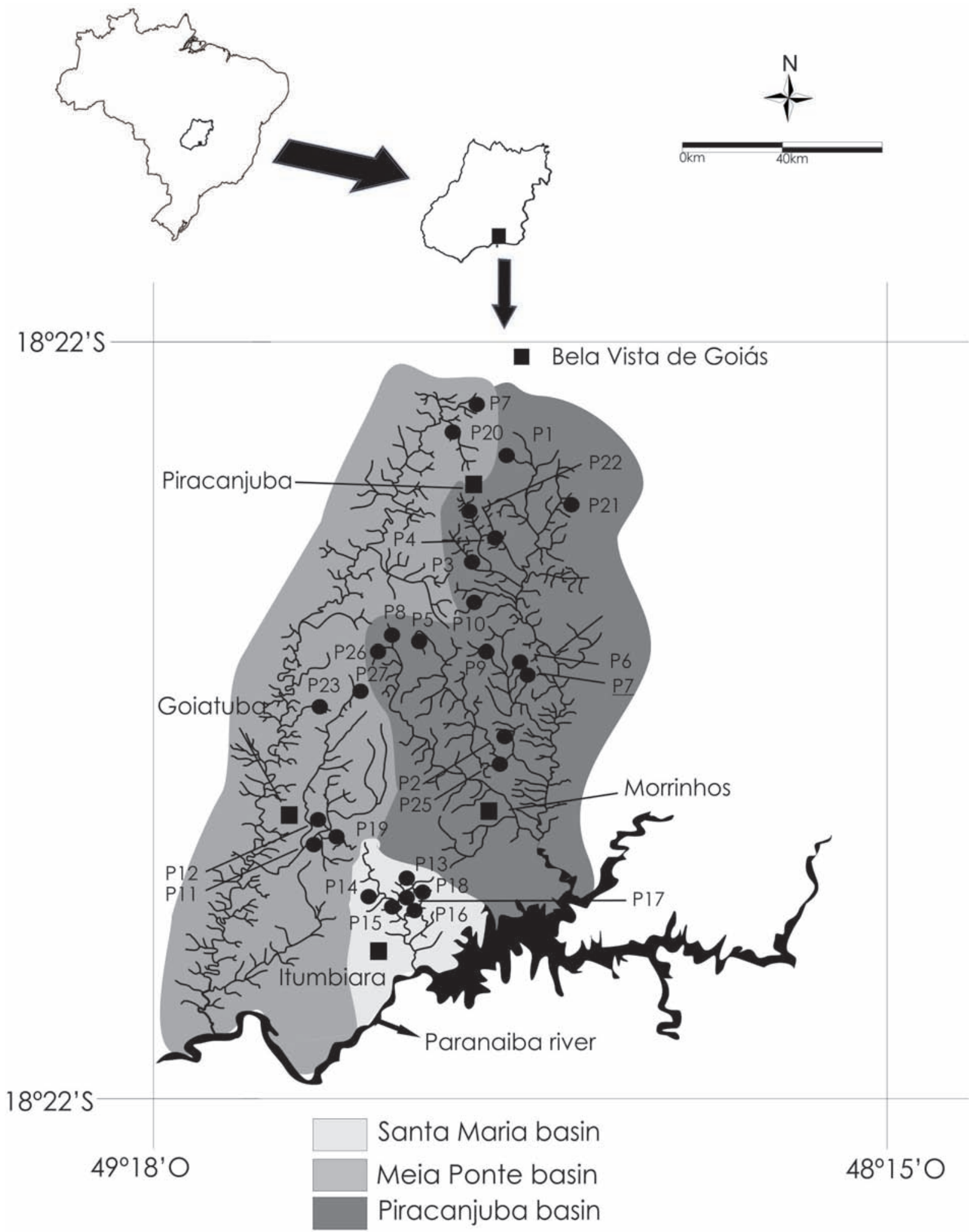

Fig. 1. Location of streams sampled (black circles) from April to September, 2009, in the Upper Paraná River basin, Central Brazil. The black squares represent the main urban areas. The black area represents the reservoir at the Itumbiara hydroelectric plant. 
or part of the population supported by the same energy source (Burns, 1989). Both analyzes were followed by a post-hoc Tukey analysis. All tests were carried out in the Statistica 8.0 software (StATSoft InC., 2007).

\section{RESULTS}

A total of 4,870 individuals were collected distributed in 59 species and 19 families (Tab. II). The GLMM with nested design indicates that the observed richness and omnivore biomass of the fish assemblages sampled were influenced by the interaction of the stream order and basin factors. Richness is not influenced by abundance (Tab. III).

The $2^{\text {nd }}$ order streams located in Santa Maria basin presented fish assemblages with the highest values of observed richness (mean = 32 species; Fig. 2) and omnivore biomass (mean $=487$ g; Fig. 3 ). These values are significantly different from the fish assemblages of $1^{\text {st }}$ order streams in the same basin (only richness), streams of the Piracanjuba River basin ( $1^{\text {st }}$ order for richness; both stream orders for omnivore biomass; Tab. IV) or those of the Meia Ponte River basin (both stream orders for richness and omnivore biomass; Tab. IV).
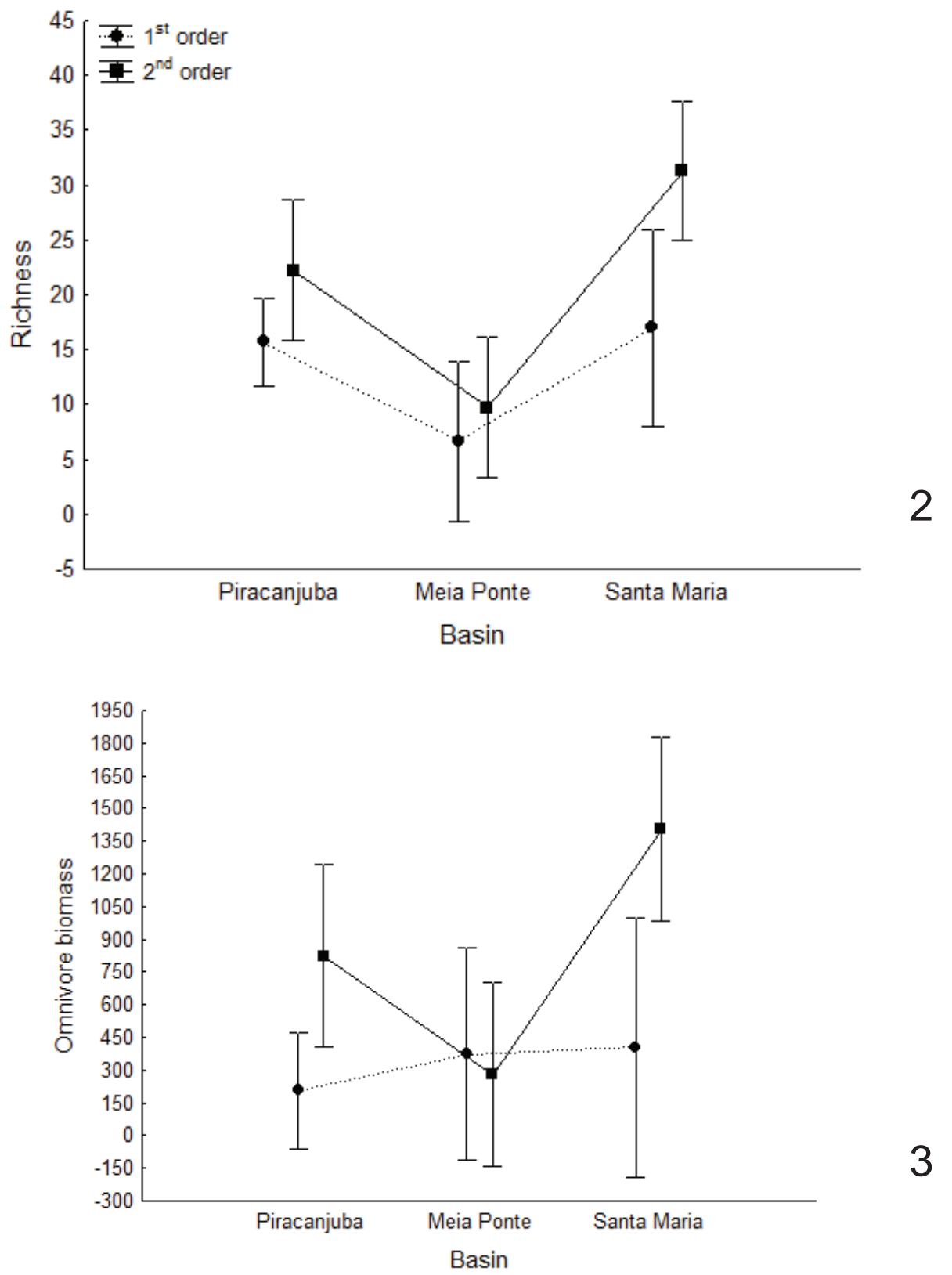

3

Figs 2, 3. Plot resulting of the generalized linear mixed models (GLMM) with nested design analysis for observed fish richness (2) and omnivore trophic guild (3) per stream order and basin sampled in the Upper Paraná River basin, Central Brazil, between April and September, 2009. The vertical bars represent the confidence interval of $95 \%$. 
Tab. II. Number of individuals and trophic guild according to the literature per fish species collected in the 27 streams sampled in the Upper Paraná River basin, Central Brazil, between April and September, 2009.

\begin{tabular}{|c|c|c|c|}
\hline $\begin{array}{l}\text { ORDER } \\
\text { Family } \\
\text { Species }\end{array}$ & $\begin{array}{c}\text { Number } \\
\text { of individuals }\end{array}$ & Trophic guild & Reference \\
\hline \multicolumn{4}{|l|}{ CHARACIFORMES } \\
\hline \multicolumn{4}{|l|}{ Anostomidae } \\
\hline Leporinus microphtalmus Garavello, 1989 & 57 & Omnivore & Albrecht \& P.-CARAMASChI, 2003 \\
\hline \multicolumn{4}{|l|}{ Characidae } \\
\hline Astyanax altiparanae Garutti \& Britski, 2000 & 615 & Omnivore & Graça \& Pavanelli, 2007 \\
\hline Astyanax eigenmanniorum (Cope, 1894) & 240 & Omnivore & Grosman et al., 1996 \\
\hline Astyanax fasciatus (Cuvier, 1819) & 679 & Omnivore & Graça \& Pavanelli, 2007 \\
\hline Astyanax scabripinnis (Jenyns, 1842) & 356 & Omnivore & CAStro \& CASATTi, 1997 \\
\hline Astyanax sp. 1 & 1 & Omnivore & Graça \& Pavanelli, 2007 \\
\hline Astyanax sp. 2 & 1 & Omnivore & Graça \& Pavanelli, 2007 \\
\hline Bryconamericus stramineus Eigenmann, 1908 & 728 & Insectivore & BRANDÃo-GonÇALVES et al., 2009 \\
\hline Knodus sp. & 19 & Omnivore & SANTOS et al., 2004 \\
\hline Oligosarcus planaltinae Menezes \& Géry, 1983 & 16 & Carnivore & Fialho \& Tejerina-Garro, 2004 \\
\hline Piabina argentea Reinhardt,1867 & 401 & Insectivore & FERREIRA et al., 2002 \\
\hline Planaltina myersi Böhlke, 1954 & 18 & Omnivore & SCHNEIDER et al., 2011 \\
\hline Serrapinnus sp. & 27 & Insectivore & GoMiero \& BRAGA, 2008 \\
\hline \multicolumn{4}{|l|}{ Crenuchidae } \\
\hline Characidium fasciatum Reinhardt, 1867 & 31 & Insectivore & CASATTI \& CASTRO, 1998 \\
\hline Characidium gomesi Travassos, 1956 & 36 & Insectivore & CAStro \& Casatti, 1997 \\
\hline Characidium sp. & 14 & Insectivore & Graça \& PaVanelli, 2007 \\
\hline Characidium zebra Eigenmann, 1909 & 51 & Insectivore & Graça \& PaVanelli, 2007 \\
\hline \multicolumn{4}{|l|}{ Curimatidae } \\
\hline Cyphocharax modestus (Fernández-Yépez, 1948) & 2 & Detritivore & Graça \& Pavanelli, 2007 \\
\hline Steindachnerina insculpta (Fernández-Yépez, 1948) & 200 & Detritivore & Graça \& PaVanelli, 2007 \\
\hline \multicolumn{4}{|l|}{ Erythrinidae } \\
\hline Hoplias malabaricus (Bloch, 1794) & 9 & Carnivore & Graça \& Pavanelli, 2007 \\
\hline \multicolumn{4}{|l|}{ Lebiasinidae } \\
\hline Pyrrhulina australis Eigenmann \& Kennedy, 1903 & 1 & Omnivore & CASATTI et al., 2001 \\
\hline \multicolumn{4}{|l|}{ Parodontidae } \\
\hline Apareiodon ibitiensis Amaral Campos, 1944 & 70 & Detritivore & Graça \& PaVanelli, 2007 \\
\hline Apareiodon vladii Pavanelli, 2006 & 1 & Detritivore & Graça \& PaVanelli, 2007 \\
\hline Parodon nasus Kner, 1859 & 35 & Detritivore & GoMiero \& Braga, 2008 \\
\hline \multicolumn{4}{|l|}{ Prochilodontidae } \\
\hline Prochilodus lineatus (Valenciennes, 1837) & 3 & Detritivore & RESENDE et al., 1996 \\
\hline \multicolumn{4}{|l|}{ Poeciliidae } \\
\hline Poecilia reticulata Peters, 1859 & 133 & Insectivore & Luz-Agostinho et al., 2006 \\
\hline \multicolumn{4}{|l|}{ GYMNOTIFORMES } \\
\hline \multicolumn{4}{|l|}{ Gymnotidae } \\
\hline Gymnotus carapo Linnaeus, 1758 & 23 & Carnivore & SANTOS et al., 2004 \\
\hline \multicolumn{4}{|l|}{ Sternopygidae } \\
\hline Eigenmannia trilineata López \& Castello, 1966 & 11 & Insectivore & Peretti \& Adrian, 1999 \\
\hline \multicolumn{4}{|l|}{ PERCIFORMES } \\
\hline \multicolumn{4}{|l|}{ Cichlidae } \\
\hline Cichla kelberi Kullander \& Ferreira, 2006 & 2 & Carnivore & Graça \& PaVanelli, 2007 \\
\hline Cichlasoma paranaense Kullander, 1983 & 19 & Insectivore & Graça \& Pavanelli, 2007 \\
\hline Crenicichla niederleinii (Holmberg, 1891) & 30 & Insectivore & HAHN et al., 1998 \\
\hline Oreochromis niloticus (Linnaeus, 1758) & 2 & Omnivore & GRAÇA \& PaVANELli, 2007 \\
\hline Tilapia rendalli (Boulenger, 1897) & 11 & Omnivore & FialHo \& TEJERINA-GARRo, 2004 \\
\hline SILURIFORMES & & & \\
\hline Aspredinidae & & & \\
\hline Bunocephalus coracoideus (Cope, 1874) & 4 & Carnivore & SANTOS et al., 2004 \\
\hline Auchenipteridae & & & \\
\hline Tatia neivai (Ihering, 1930) & 2 & Omnivore & CASATTI et al., 2001 \\
\hline Callichthyidae & & & \\
\hline Aspidoras fuscoguttatus Nijssen \& Isbrücker, 1976 & 369 & Insectivore & SCHNEIDER et al., 2011 \\
\hline Corydoras flaveolus Ihering, 1911 & 17 & Insectivore & CASATTI et al., 2001 \\
\hline Heptapteridae & & & \\
\hline Cetopsorhamdia iheringi Schubart \& Gomes, 1959 & 24 & Insectivore & Graça \& PaVanelli, 2007 \\
\hline Cetopsorhamdia sp. & 33 & Insectivore & Graça \& PaVAnelli, 2007 \\
\hline Heptapterus sp. & 1 & Insectivore & SAZIMA, 1986 \\
\hline Imparfinis longicaudus (Boulenger, 1887) & 5 & Omnivore & GraÇa \& PaVAnelli, 2007 \\
\hline Imparfinis sp. & 24 & Omnivore & Graça \& Pavanelli, 2007 \\
\hline Phenacorhamdia sp. & 4 & Insectivore & SAZIMA, 1986 \\
\hline
\end{tabular}




\begin{tabular}{|c|c|c|c|}
\hline Phenacorhamdia tenebrosa (Schubart, 1964) & 14 & Insectivore & SAZIMA, 1986 \\
\hline Pimelodella sp. & 49 & Carnivore & SANTOS et al., 2004 \\
\hline Rhamdia quelen (Quoy \& Gaimard, 1824) & 147 & Carnivore & Graça \& Pavanelli, 2007 \\
\hline \multicolumn{4}{|l|}{ Loricariidae } \\
\hline Hisonotus sp. & 2 & Detritivore & CASATTI et al., 2001 \\
\hline Hypostomus ancistroides (Ihering, 1911) & 168 & Detritivore & Graça \& Pavanelli, 2007 \\
\hline Hypostomus cf. strigaticeps (Regan, 1908) & 2 & Detritivore & Graça \& Pavanelli, 2007 \\
\hline Hypostomus plecostomus (Linnaeus, 1758) & 5 & Detritivore & MÉRONA \& R.-DE-MÉRONA, 2004 \\
\hline Hypostomus regani (Ihering, 1905) & 44 & Detritivore & GraÇA \& PaVAnelli, 2007 \\
\hline Hypostomus sp. 1 & 28 & Detritivore & Graça \& Pavanelli, 2007 \\
\hline Hypostomus sp. 2 & 16 & Detritivore & Graça \& Pavanelli, 2007 \\
\hline Hypostomus sp. 3 & 46 & Detritivore & Graça \& Pavanelli, 2007 \\
\hline Loricaria sp. & 2 & Detritivore & Graça \& Pavanelli, 2007 \\
\hline Rineloricaria latirostris (Boulenger, 1900) & 13 & Insectivore & Jussara Souza, unpublished DATa \\
\hline \multicolumn{4}{|l|}{ Trichomycteridae } \\
\hline Trichomycterus sp. & 1 & Insectivore & CAsatti, 2002 \\
\hline \multicolumn{4}{|l|}{ SYNBRANCHIFORMES } \\
\hline \multicolumn{4}{|l|}{ Synbranchidae } \\
\hline Synbranchus marmoratus Bloch, 1795 & 8 & Carnivore & SANTOS et al., 2004 \\
\hline
\end{tabular}

Tab. III. Statistics of the generalized linear mixed models (GLMM) with nested design (stream order and basin) analysis for observed fish richness and biomass per trophic guild of the 27 streams sampled in the Upper Paraná River basin, Central Brazil, between April and September, 2009 (*, significant differences, $\mathrm{P}<0.05$; DF, degree of freedom).

\begin{tabular}{|c|c|c|c|c|c|c|}
\hline $\begin{array}{l}\text { Dependent } \\
\text { variable }\end{array}$ & & Parameter & Effect & $\mathrm{DF}$ & $\mathrm{F}$ & $\mathrm{P}$ \\
\hline \multirow{4}{*}{ 总 } & & Order & Fixed & 1 & 15.400 & 0.058 \\
\hline & & Basin & Random & 2 & 3.222 & 0.175 \\
\hline & & Order vs. Basin & Random & 3 & 3.671 & $0.029 *$ \\
\hline & & Abundance & Random & 20 & 19.475 & 0.177 \\
\hline \multirow{12}{*}{ 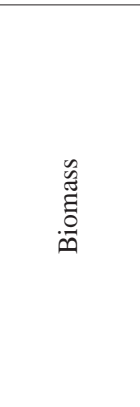 } & \multirow{3}{*}{ Carnivore } & Order & Fixed & 1 & 6.872 & 0.113 \\
\hline & & Basin & Random & 2 & 0.406 & 0.750 \\
\hline & & Order vs. Basin & Random & 3 & 3.269 & 0.147 \\
\hline & \multirow{3}{*}{ Detritivore } & Order & Fixed & 1 & 5.388 & 0.141 \\
\hline & & Basin & Random & 2 & 1.416 & 0.362 \\
\hline & & Order vs. Basin & Random & 3 & 1.464 & 0.253 \\
\hline & \multirow{3}{*}{ Insectivore } & Order & Fixed & 1 & 9.580 & 0.086 \\
\hline & & Basin & Random & 2 & 2.174 & 0.250 \\
\hline & & Order vs. Basin & Random & 3 & 1.152 & 0.351 \\
\hline & \multirow{3}{*}{ Omnivore } & Order & Fixed & 1 & 14.51 & 0.060 \\
\hline & & Basin & Random & 2 & 0.661 & 0.577 \\
\hline & & Order vs. Basin & Random & 3 & 4.957 & $0.009 *$ \\
\hline
\end{tabular}

\section{DISCUSSION}

Only the interaction of the basin and stream order shows an influence on fish assemblage. This result expresses the influence of geomorphic processes on fish assemblages (Montgomery, 1999; Magalhães et al., 2002), that is, the Santa Maria River basin is characterized by the widest and deepest stream channel with greater water velocity than streams of the other basins. These characteristics increase habitat heterogeneity (GORMAN \& KARR, 1978) and availability of resources, thereby increasing the potential number of niches, which in turn facilitates the coexistence of more species (WINEMILLER et al., 2008; Hugueny et al., 2010). This seem be expressed in this study by the differences among streams of $2^{\text {nd }}$ order of the Santa Maria River basin and streams of $1^{\text {st }}$ and $2^{\text {nd }}$ order of the Piracanjuba and Meia Ponte Rivers basins. On the other hand, the absence of differences between the streams of the Piracanjuba and Meia Ponte Rivers basins can be related to the similarity of the habitat, supporting the idea that streams of equal order, even if located in different basins, would present similar fish assemblage in terms of species richness and abundance (VANNOTE et al., 1980).

The results of this study also suggest that the structure of fish assemblages increases in richness and omnivore biomass in accordance with increases in stream order (from $1^{\text {st }}$ to $2^{\text {nd }}$ order). Different studies report this trend for fish richness [e. g., Platts (1979) from $1^{\text {st }}$ to $5^{\text {th }}$ order; Smith $\&$ Kraft $(2005)-1^{\text {st }}$ to $3^{\text {rdd }}$; Osborne $\&$ WILEY (1992) - $1^{\text {st }}$ to $\left.5^{\text {th }}\right]$. In this study, this trend seems to be supported by changes in stream characteristics (width, depth and current increase as stream order increases) as 
Tab. IV. Statistics of the post-hoc analysis of the generalized linear mixed models (GLMM) with nested design (stream order and basin) for observed fish richness (a) and biomass of the (b) carnivore, (c) detritivore, (d) insectivore and (e) omnivore trophic guild of the 27 streams sampled in the Upper Paraná River basin, Central Brazil, between April and September, 2009. * = Significant differences $(\mathrm{P}<0.05)$.

\begin{tabular}{|c|c|c|c|c|}
\hline \multirow[t]{2}{*}{ Basin } & \multirow[b]{2}{*}{ Order } & \multicolumn{2}{|c|}{ Meia Ponte } & Santa Maria \\
\hline & & $1^{\mathrm{st}}$ & $2^{\text {nd }}$ & $2^{\text {nd }}$ \\
\hline \multirow{3}{*}{ Piracanjuba } & $1^{\mathrm{st}}$ & 0.258 & 0.577 & $.004 *$ \\
\hline & $2^{\text {nd }}$ & 0.317 & 0.080 & 0.331 \\
\hline & $1^{\mathrm{st}}$ & - & 0.984 & $.001 *$ \\
\hline Meia Ponte & $2^{\text {nd }}$ & & - & $.001 *$ \\
\hline \multirow{2}{*}{ Santa Maria } & $1^{\mathrm{st}}$ & & & $.012^{*}$ \\
\hline & $2^{\text {nd }}$ & & & 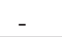 \\
\hline \multirow{2}{*}{ Piracanjuba } & $1^{\text {st }}$ & 0.998 & 0.934 & 0.628 \\
\hline & $2^{\text {nd }}$ & 0.969 & 0.818 & 0.952 \\
\hline \multirow{2}{*}{ Meia Ponte } & $1^{\mathrm{st}}$ & - & 0.999 & 0.624 \\
\hline & $2^{\text {nd }}$ & & - & 0.330 \\
\hline \multirow{2}{*}{ Santa Maria } & $1^{\text {st }}$ & & & 0.944 \\
\hline & $2^{\text {nd }}$ & & & - \\
\hline \multirow{2}{*}{ Piracanjuba } & $1^{\mathrm{st}}$ & 0.778 & 0.840 & 0.399 \\
\hline & $2^{\text {nd }}$ & 0.801 & 0.860 & 0.675 \\
\hline \multirow{2}{*}{ Meia Ponte } & $1^{\mathrm{st}}$ & - & 1.000 & 0.131 \\
\hline & $2^{\text {nd }}$ & & - & 0.135 \\
\hline \multirow[t]{2}{*}{ Santa Maria } & $1^{\text {st }}$ & & & 0.336 \\
\hline & $2^{\text {nd }}$ & & & - \\
\hline \multirow{2}{*}{ Piracanjuba } & $1^{\mathrm{st}}$ & 0.383 & 0.805 & 0.825 \\
\hline & $2^{\text {nd }}$ & 0.557 & 0.906 & 0.896 \\
\hline \multirow{2}{*}{ Meia Ponte } & $1^{\mathrm{st}}$ & - & 0.975 & 0.128 \\
\hline & $2^{\text {nd }}$ & & - & 0.341 \\
\hline \multirow{2}{*}{ Santa Maria } & $1^{\mathrm{st}}$ & & & 0.543 \\
\hline & $2^{\text {nd }}$ & & & - \\
\hline \multirow{2}{*}{ Piracanjuba } & $1^{\mathrm{st}}$ & 0.988 & 1.000 & $.001^{*}$ \\
\hline & $2^{\text {nd }}$ & 0.690 & 0.425 & $.036 *$ \\
\hline \multirow{2}{*}{ Meia Ponte } & $1^{\text {st }}$ & - & 1.000 & $.032 *$ \\
\hline & $2^{\text {nd }}$ & & - & $.009 *$ \\
\hline \multirow{2}{*}{ Santa Maria } & $1^{\mathrm{st}}$ & & & 0.088 \\
\hline & $2^{\text {nd }}$ & & & - \\
\hline
\end{tabular}

mentioned above and observed by CASATTI (2005) and DiAs \& TeJERINA-GARRo (2010) in tropical streams, and by IBAÑEZ et al. (2009) in tropical and temperate streams. However, it is necessary to stress that other factors not measured in this study can also influence these results such as the shorter distance of the fish assemblage of the streams of $2^{\text {nd }}$ order from downstream source fish populations, the reduced barriers to fish migration from downstream locations to $2^{\text {nd }}$ stream order, and more stable habitats of $2^{\text {nd }}$ stream order than those of $1^{\text {st }}$ order (WINEmiller et al., 2008). Additionally, the extent of anthropogenic activities in each basin can influence on obtained results, once this induces changes of the fish assemblage structure as observed by Fialho et al. (2008) in the Meia Ponte basin.

The increase of omnivore biomass as stream order increases can be a consequence of food availability. The supply of food resources in a stream of $2^{\text {nd }}$ order comes from two main sources, the adjacent riparian forest and the resources brought by its tributaries. In other words, food availability tends to be greater than that of streams located at the headwaters, $1^{\text {st }}$ order in this case (REDFORD \& FonSECA, 1996; RAKOCINSKI et al., 1997). However, even in streams of $2^{\text {nd }}$ order food availability is not constant along time and is influenced by environmental constraints, which led to trophic constraints of fish assemblages and finally to differing proportions of trophic guilds (IBAÑEZ et al., 2009), omnivores in this case. In tropical streams one environmental constraint influencing food availability and trophic composition is the climate characterized by rainy and dry seasons, as observed in the basins sampled. Accordingly to WinemiLler et al. (2008) during the dry season food resources are limited and in these circumstances some tropical fish species present more specialized feeding habits based on their morphology that allows for relative foraging efficiency. In this situation, the omnivore species could be the least influenced due to their broad dietary options (Uieda \& MotTA, 2007).

It is concluded that the fish assemblage is influenced by the interaction of stream order and basin factors resulting in a significant increase of richness and omnivore biomass from streams of $1^{\text {st }}$ to $2^{\text {nd }}$ order. However, additional studies including higher orders than those considered are necessary aiming to verify the achievement of results obtained.

Acknowledgements. We would like to thank the team at the Center for Aquatic Biology/PUC Goiás, in the person of Mr. Waldeir Francisco de Menezes for collaborating with data collection in the field, two anonymous reviewers for their suggestions, the CNPq for the scholarship granted to TBV and to CNPq and FAPEG for financing the projects of which this study is part. 


\section{REFERENCES}

Albrecht, M. P. \& Pellegrini-Caramaschi, E. 2003. Feeding ecology of Leporinus taeniofasciatus (Characiformes: Anostomidae) before and after installation of a hydroelectric plant in the upper rio Tocantins, Brazil. Neotropical Ichthyology 1(1):53-60.

AraúJo, N. B. \& Tejerina-GarRo, F. L. 2009. Influence of environmental variables and anthropogenic perturbations on stream fish assemblages, Upper Paraná River, Central Brazil. Neotropical Ichthyology 7(1):18.

Beecher, H.; Dott, E. \& Fernau, R. 1988. Fish species richness and stream order in Washington State streams. Environmental Biology of Fishes 22:193-209.

Brandão-Gonçalves, L.; Lima-Junior, S. L. \& Suarez, Y. R. 2009. Hábitos alimentares de Bryconamericus stramineus Eigenmann, 1908 (Characidae), em diferentes riachos da sub-bacia do Rio Guiraí, Mato Grosso do Sul, Brasil. Biota Neotropica 9(1):135-143.

Brasil. 1977. Geografia do Brasil - Região Centro-Oeste. Rio de Janeiro, Fundação Instituto Brasileiro de Geografia e Estatística. 364p.

BuRns, T. P. 1989. Lindeman's contradiction and the trophic structure of ecosystems. Ecology 70(5):1355-1362.

CAsatti, L. 2002. Alimentação dos peixes em um riacho do Parque Estadual Morro do Diabo, bacia do alto rio Paraná, sudeste do Brasil. Biota Neotropica 2(2):1-14.

2005. Fish assemblage structure in a first order stream, southeastern Brazil: longitudinal distribution, seasonality, and microhabitat diversity. Biota Neotropica 5(1):1-9.

Casatti, L. \& Castro, R. M. C. 1998. A fish community of the São Francisco River headwaters riffles, southeastern Brazil. Ichthyological Exploration of Freshwaters 9:229-242.

Casatti, L.; Langeani, F. \& Castro, R. M. C. 2001. Peixes de riacho do Parque Estadual Morro do Diabo, bacia do alto rio Paraná, SP. Biota Neotropica 1(1):1-15.

Castro, R. M. C. \& CASATti, L. 1997. The fish fauna from a small forest stream of the upper Parana River basin, southeastern Brazil. Ichthyological Exploration of Freshwaters 7:337-352.

Dias, A. M. \& Tejerina-Garro, F. L. 2010. Changes in the structure of fish assemblages in streams along an undisturbed-impacted gradient, upper Paraná River basin, Central Brazil. Neotropical Ichthyology 8(3):587-598.

Ferreira, A.; Hahn, N. S. \& Delariva, R. L. 2002. Ecologia alimentar de Piabina argentea (Teleostei, Tetragonopterinae) nas fases de pré e pós-represamento do rio Corumbá, GO. Acta Limnologica Brasiliensia 14(2):43-52.

Fialho, A. P.; Oliveira, L. G.; Tejerina-Garro, F. L. \& Gomes, L. C. 2007. Fish assemblage structure in tributaries of the Meia Ponte River, Goiás, Brazil. Neotropical Ichthyology 5(1):53-60.

Fialho, A. P.; Oliveira, L. G.; Tejerina-Garro, F. L. \& Mérona, B. 2008. Fish-habitat relationship in a tropical river under anthropogenic influences. Hydrobiologia 598:315-324.

Fialho, A. P. \& Tejerina-Garro, F. L. 2004. Peixes da Bacia do Rio Meia Ponte, GO. Goiânia, Editora da UCG. 105p.

Giller, P. S. \& MALMQVist, B. 1998. The biology of streams and rivers. Oxford, Oxford University Press. 296p.

Gomiero, L. M. \& Braga, F. M. S. 2008. Feeding habits of the ichthyofauna in a protected area in the state of São Paulo, southeastern Brazil. Biota Neotropica 8(1):41-47.

Gorman, O. T. \& KarR, J. R. 1978. Habitat structure and stream fish communities. Ecology 59:507-515.

GraçA, W. J. \& PaVANelli, C. S. 2007. Peixes da planície de inundação do alto rio Paraná e áreas adjacentes. Maringá, EDUEM. 241p.

Grosman, M. F.; Castelain, G. \& UsunofF, E. J. 1996. Trophic niches in an Argentine pond as a way to assess functional relationships between fishes and other communities. Water SA-Pretoria 22:345-350.

Hahn, N. S.; Agostinho, A. A.; Gomes, L. C. \& Bin, L. M. 1998. Estrutura trófica da ictiofauna do reservatório de Itaipu (Paraná-Brasil) nos primeiros anos de sua formação. Interciencia 23:299-305.

HaRrel, R. C.; DAVIS, B. J. \& DorRIS, T. C. 1967. Stream order and species diversity of fishes in an intermittent Oklahoma stream. American Midland Naturalist 78(2):428-436.
Hugueny, B.; OberdorfF, T. \& Tedesco, P. A. 2010. Community ecology of river fishes: a large-scale perspective. American Fisheries Society 73:29-62.

Ibañez, C.; Belliard, J.; Hughes, R. M.; Irz, P.; Kamdem-Toham, A.; Lamouroux, N.; Tedesco, P. A. \& OberdorfF, T. 2009. Convergence of temperate and tropical stream fish assemblages. Ecography 32:658-670.

Jones III, E. B. D.; Helfman, G. S.; Harper, J. O. \& Bolstad, P. V. 1999. Effects of riparian forest removal on fish assemblages in Southern Appalachian streams. Conservation Biology 13(6):1454-1465.

KASHIWAGI, M. T. \& MirANDA, L. E. 2009. Influence of small impoundments on habitat and fish communities in headwater streams. Southeastern Naturalist 8(1):23-36.

LuZ-Agostinho, K. D. G.; BinI, L. M.; Fugi, R.; Agostinho, A. \& Júlio JR., H. F. 2006. Food spectrum and trophic structure of the ichthyofauna of Corumbá reservoir, Paraná river Basin, Brazil. Neotropical Ichthyology 4(1):61-68.

Magalhães, M. F.; Batalha, D. C. \& Collares-Pereira, M. J. 2002. Gradients in stream fish assemblages across a Mediterranean landscape: contributions of environmental factors and spatial structure. Freshwater Biology 47:1015-1031.

Matthews, W. 1986. Fish faunal "break" and stream order in the eastern and central United States. Environmental Biology of Fishes 17:8192.

Mazzoni, R.; Fenerich-Verani, N. \& Caramaschi, E. P. 2000. A pesca elétrica como técnica de amostragem de populações e comunidades de peixes em rios costeiros do sudeste do Brasil. Revista Brasileira de Biologia 60(2):205-216.

Meffe, G. K. \& Berra, T. M. 1988. Temporal characteristics of fish assemblage structure in an Ohio stream. Copeia 3:684-691.

Mérona, B. de \& RANKIn-DE-Mérona, J. 2004. Food resource partitioning in a fish community of the Central Amazon floodplain. Neotropical Ichthyology 2:75-84.

MonTGOMERY, D. R. 1999. Process domains and the river continuum. Journal of American Water Resources Association 35(2):397-410.

OsBorNe, L. L. \& WiLEY, M. J. 1992. Influence of tributary spatial position on the structure of warmwater fish communities. Canadian Journal of Fisheries and Aquatic Sciences 49:671-681.

PaLLER, M. H. 1994. Relationships between fish assemblage structure and stream order in South Carolina coastal plain streams. Transactions of the American Fisheries Society 123(2):150-161.

Pease, A. A.; González-Díaz, A. A.; Rodiles-Hernández, R. \& Winemiller, K. O. 2012. Functional diversity and trait-environment relationships of stream fish assemblages in a large tropical catchment. Freshwater Biology 57:1060-1075.

Peretti, D. \& Andrian, I. De F. 1999. Feeding of Eigenmannia trilineata (Pisces, Sternopygidae) (Lopez \& Castello, 1966), in the upper Paraná River floodplain, Brazil. Brazilian Archives of Biology and Technology 42(1):77-84.

PetTs, G. E. 1994. Rivers: dynamic components of catchment ecosystems. In: Calow, P. \& Petts, G. E. eds. The River Handbook. Oxford, Blackwell Scientific. v.2. p.3-22.

PlatTs, W. S. 1979. Relationships among stream order, fish populations, and aquatic geomorphology in an Idaho River drainage. Fisheries 4(2):5-9.

Rakocinski, C. F.; Brown, S. S.; Gaston, G. R.; Heard, R. W.; Walker, W. W. \& Summers, J. K. 1997. Macrobenthic responses to natural and contaminant-related gradients in northern Gulf of Mexico estuaries. Ecological Applications 7(4):1278-1298.

Redford, K. H. \& FonseCA, G. A. B. 1996. The role of gallery forests in the zoogeography of the cerrado's nonvolant mammalian fauna. Biotropica 18(2):126-135.

Resende, E. K.; Catella, A. C.; Nascimento, F. L.; Palmeira, S. S.; CÂndido, R. A.; Lima, M. S. \& Almeida, V. L. L. 1996. Biologia do curimbatá (Prochilodus lineatus), pintado (Psudoplatystoma corruscans) e cachara (Pseudoplatystoma fasciatum) na bacia hidrográfica do rio Miranda, Pantanal, Mato Grosso do Sul, Brasil. EMBRAPA/CPAP Boletim de Pesquisa 2:1-75.

Santos, G. M.; Mérona, B.; Juras, A. A. \& Jégu, M. 2004. Peixes do baixo rio Tocantins: 20 anos depois da Usina Hidrelétrica Tucuruí. Brasília, Eletronorte. 216p. 
SAzImA, I. 1986. Similarities in feeding behaviour between some marine and freshwater fishes in two tropical communities. Journal of Fish Biology 29:53-65.

Schneider, M.; Aquino, P. D. P. U.; Silva, M. J. M. \& Fonseca, C. P. 2011. Trophic structure of a fish community in Bananal stream sub-basin in Brasília National Park, Cerrado biome (Brazilian Savanna), DF. Neotropical Ichthyology 9(3):579-592.

Sistema Estadual de Estatística e InFormações Geográficas de Goiás. 2013. Available at: <http://www.sieg.go.gov.br>. Accessed in 12 April 2013

Smiley Jr, P. C.; Dibble, E. D. \& Schoenholtz, S. H. 2005. Fishes of First-Order Streams in North-Central Mississippi. Southeastern Naturalist 4:219-236.

Smith, T. A. \& Kraft, C. E. 2005. Stream Fish Assemblages in Relation to Landscape Position and Local Habitat Variables. Transactions of the American Fisheries Society 134:430-440.

StatSoft, Inc. 2007. Statistica (data analysis software system), version 8.0. Available at <http://www.statsoft.com>. Accessed in April 2013.

STRAHLER, A. N. 1957. Quantitative analysis of watershed geomorphology. Transactions of the American Geophysical Union 38:913-920.
TAYlor, B. W.; Flecker, A. S. \& Hall JR., R. O. 2006. Loss of a harvested fish species disrupts carbon flow in a diverse tropical river. Science 313(5788):833-836.

UiedA, V. S. \& MotтA, R. L. 2007. Trophic organization and food web structure of southeastern Brazilian streams: a review. Acta Limnologica Brasiliensia 19:15-30.

Vannote, R. L.; Minshall, G. W.; Cummins, K. W.; Sedell, J. R. \& Cushing, C. E. 1980. The river continuum concept. Canadian Journal of Fisheries and Aquatic Science 37(1):130-137.

Walker, I.; Henderson, P. \& Sterry, P. 1990. On the patterns of biomass transfer in the benthic fauna of an Amazonian black-water river, as evidenced by P-32 label experiment. Hydrobiologia 12:23-34.

Whiteside, B. G. \& McNatt, R. M. 1972. Fish species diversity in relation to stream order and physicochemical conditions in the Plum Creek drainage basin. American Midland Naturalist 88(1):90-101.

Winemiller, K. O.; Agostinho, A. A. \& Caramaschi, E. P. 2008. Fish ecology in tropical streams. In: DudGEON, D. ed. Tropical stream ecology. Amsterdam, Elsevier. p.107-146. 